\title{
Edukasi Covid-19 Melalui Program KKN Covid UNS Mewujudkan Karakter Hidup Bersih di Desa Selourik, Ngargoyoso, Karanganyar
}

\author{
Gifari Ilham Ramadhan', Valiant Lukad Perdana Sutrisno² \\ ${ }^{1}$ Mechanical Engineering Education The Faculty of Teacher Training and Education \\ Sebelas Maret University Indonesia \\ ${ }^{2}$ Mechanical Engineering Education The Faculty of Teacher Training and Education \\ Sebelas Maret University Indonesia \\ Corresponding email:1 gifari.ilham@student.uns.ac.id 22 valiantlps@staff.uns.ac.id
}

\begin{abstract}
Real Work Lecture (KKN) Coronavirus or Severe Acute Respiratory Syndrome Coronavirus 2 (SARS-CoV-2) is a virus that attacks the respiratory system. The disease caused by this viral infection is called COVID-19. Coronavirus can cause mild respiratory disease, severe lung infections and death. The way to prevent this is to follow the existing health procedures by always washing hands, keeping your distance, staying at home without emergency benefits, and protecting your immune system. My goal in implementing the Covid-19 community service plan is to provide knowledge to the public about this corona virus, as well as provide education or counseling to people infected with Covid-19. In order to carry out this KKN activity, this activity is carried out directly or indirectly. Provide information online or in direct dialogue with residents about how to prevent the corona virus, and provide information to school-age children who are affected. Collect data about communities affected by covid-19. The indirect way this is done is by sending and explaining via the whatsapp media. Providing education to children through a fun and effective learning process so that they don't get bored easily, also providing videos on effective learning methods to increase people's knowledge and understanding of effective learning methods.
\end{abstract}

Keywords: Positive cases; Corona; Covid-19; Pandemic; Socialization; Education 


\begin{abstract}
ABSTRAK
Kuliah Kerja Nyata (KKN) Coronavirus atau Severe Acute Respiratory Syndrome Coronavirus 2 (SARS-CoV-2) merupakan virus yang menyerang sistem pernafasan. Penyakit yang disebabkan oleh infeksi virus ini disebut COVID-19. Cara pencegahannya adalah dengan mengikuti prosedur kesehatan yang ada dengan selalu cuci tangan, menjaga jarak, tinggal di rumah tanpa manfaat darurat, dan melindungi kekebalan tubuh. Tujuan saya dalam mengimplementasikan rencana pengabdian masyarakat Covid-19 adalah memberikan pengetahuan kepada masyarakat tentang virus corona ini, serta memberikan edukasi atau penyuluhan kepada orang-orang yang terinfeksi Covid19. Dalam rangka melaksanakan kegiatan KKN ini, dilakukan kegiatan ini secara langsung maupun tidak langsung. Meberikan informasi secara online ataupun berdialog langsung dengan warga tentang cara pencegahan virus corona, dan memberikan informasi kepada anak-anak usia sekolah yang terkena dampak. Kumpulkan data tentang komunitas yang terkena covid-19. Cara tidak langsung yang dilakukan adalah dengan mengirim dan menjelaskan melalui media whatsapp. Memberikan edukasi kepada anak-anak melalui proses belajar yang menyenangkan dan efektif agar mereka tidak mudah bosan, juga memberikan video cara belajar yang efektif untuk menambah pengetahuan dan pemahaman masyarakat tentang cara belajar yang efektif.
\end{abstract}

Kata kunci: Kasus Positif; Corona; Covid-19; Pandemi; Sosialisasi; Pendidikan

\title{
PENDAHULUAN
}

Organisasi Kesehatan Dunia (WHO) menjelaskan bahwa Coronavirus (Cov) merupakan virus yang menginfeksi sistem pernafasan. Infeksi virus ini disebut COVID-19. Virus Corona dapat menyebabkan flu biasa hingga penyakit yang lebih serius, seperti Middle East Respiratory Syndrome (MERS-CoV) dan Severe Acute Respiratory Syndrome (SARS-CoV). Virus Corona bersifat zoonosis, artinya menyebar antara hewan dan manusia. Menurut Kementerian Kesehatan Indonesia, perkembangan kasus COVID-19 di Wuhan dimulai pada 30 
Desember 2019, ketika Komisi Kesehatan Kota Wuhan mengeluarkan pernyataan "pemberitahuan penanganan segera pneumonia yang tidak diketahui penyebabnya".

Salah satu bidang yang terdampak pandemi adalah bidang pendidikan. Kegiatan belajar mengajar yang seharusnya dilakukan secara tatap muka harus dihentikan dan beralih menjadi Work Form Home (WFH) (Siahaan, 2020). Kebijakan tersebut dilakukan guna memutus rantai penyebaran Covid-19. Kegiatan belajar di rumah tentu menyebabkan beberapa gangguan, seperti kegiatan pembelajaran siswa, penilaian yang terhambat, pembatan penilaian bahkan pembatalan dalam penerimaan seleksi pekerjaan (Syah, 2020).

Kuliah kerja Nyata merupakan kegiatan internal yang dilaksanakan untuk mewujudkan tiga hukum perguruan tinggi yaitu pendidikan, penelitian dan pengabdian kepada masyarakat (Al Hakim, 2020). Tujuan dari kegiatan KKN adalah untuk memberikan pembelajaran dan pengalaman kerja kepada siswa sehingga tidak ada jarak antara siswa dengan masyarakat di kemudian hari. Kegiatan dan pengelolaan KKN dapat menjamin pengalaman belajar yang diperoleh, sehingga kegiatan bina lingkungan dapat dilakukan dengan cara tertentu yang bermanfaat bagi siswa dan masyarakatnya. Selain itu, kegiatan dan pengelolaan KKN ditujukan untuk menghubungkan dunia akademis teoritis dengan dunia empiris. Kegiatan KKN dilaksanakan dengan memperhatikan protokol kesehatanuntuk mewujudkan Indonesia yang berdikari dan berdaulat yang teraktualisasi pada nilai-nilai integritas, gotong royong dan etos kerja (Rangki et al., 2020).

Dampak Covid-19 rata-rata mempengaruhi kehidupan masyarakat di bidang kesehatan, pendidikan, integrasi sosial dan produksi. Peraturan Pemerintah (PP) Nomor 21 Tahun 2020 dan Peraturan Menteri Kesehatan Nomor 9 Tahun 2020 tentang Pembatasan Sosial Skala Besar merupakan langkah pemerintah dalam percepatan pengobatan Penyakit Coronavirus (COVID-19) 2019. Kementerian Perdesaan, Pengembangan Kawasan Rentan, dan Imigrasi juga mengeluarkan Surat Edaran Nomor 8 Tahun 2020 tentang penanggulangan Covid- 
19 ke desa, dengan tujuan untuk meningkatkan ketahanan dan partisipasi masyarakat terhadap Covid-19.

Dusun Selourik di Desa Girimulyo, Kecamatan Ngargoyoso Karanganyar merupakan salah satu lokasi KKN yang juga telah menerapkan regulasi sanitasi, namun terkadang masih ada yang melanggar. Keadaan di desa kecil ini masih aktif, namun masih terbatas. Mulai dari karang taruna, kegiatan PKK dan paguyuban laki-laki dan perempuan setingkat sudah dibatalkan. Masih terdapat masyarakat di desa ini yang keluar rumah untuk pergi bekerja, seperti pergi ke sawah atau bekerja di luar daerah namun tidak memperharikan protokol kesehatan yang berlaku. Masyarakat di desa tersebut sendiri menghimbau untuk memakai masker, namun sebagian masyarakat masih mengabaikan peraturan tersebut.

Berdasarkan permasalah yang telah dipaparkan, tujuan dilaksanaknnya program Kuliah Kerja Nyata (KKN) UNS untuk pencegahan dan penanggulangan Covid-19 di Dusun Selourik di Desa Girimulyo, Kecamatan Ngargoyoso, Kabupaten Karanganyar. Dengan adanya kegiatan KKN diharapkan dapat memberikan solusi alternatif untuk pencegahan dan penanggulangan Covid-19.

\section{TINJAUAN PUSTAKA}

\section{Covid-19}

Coronavirus merupakan virus RNA dengan ukuran partikel 120-160 nm. Virus ini terutama menginfeksi hewan, termasuk kelelawar dan unta. Sebelum wabah Covid-19 terjadi, ada 6 jenis virus corona bisa menginfeksi manusia, virus corona 229E, alpha coronavirus NL63, beta coronavirus OC43, betacoronavirus HKU1, penyakit saluran pernapasan akut berat Coronavirus (SARS-CoV) dan Respirasi Timur Tengah Sindrom virus Corona (MERS-CoV) (Susilo et al., 2020). Coronavirus yang menjadi etiologi COVID-19 termasuk dalam genus betacoronavirus. Hasil analisis filogenetik menunjukkan bahwa virus ini masuk dalam subgenus yang sama dengan coronavirus yang menyebabkan wabah Severe Acute Respiratory Illness (SARS) pada 2002-2004 silam (Gorbalenya et al., 2020). 
Pada kasus Covid-19, trenggiling diduga sebagai reservoir perantara. Strain coronavirus pada trenggilingadalah yang mirip genomnya dengan coronavirus kelelawar (90,5\%) dan SARS-CoV-2 (91\%) (Zhang et al., 2020) Genom SARS-CoV-2 sendiri memiliki homologi 89\% terhadap coronavirus kelelawar ZXC21 dan 82\% terhadap SARS-CoV. Menurut data yang tersedia, penyakit tersebut komorbid hipertensi dan diabetes, laki-laki dan sering merokok merupakan faktor risiko infeksi SARS-CoV-2. Distribusi gender yang lebih banyak di antara pria diduga terkait dengan prevalensi perokok aktif yang lebih tinggi. Pada perokok, tekanan darah tinggi dan diabetes, diduga peningkatan ekspresi reseptor ACE2.

Beberapa faktor risiko lain ditentukan oleh faktor-faktor berikut: Pusat Pengendalian dan Pencegahan Penyakit (CDC) mempertahankan kontak dekat, termasuk tinggal serumah dengan pasien COVID-19 dan memiliki riwayat bepergian ke daerah yang terinfeksi. Pada lingkungan dengan radius tidak lebih dari 2 meter dianggap memiliki berisiko rendah untuk tertular. Perjalanan penyakit dimulai dengan masa inkubasi yang lamanya sekitar 5 hari. Pada masa ini leukosit dan limfosit masih normal atau sedikit menurun dan pasien tidak bergejala. Pada gejala awal, virus menyebar melalui aliran darah, diduga terutama pada jaringan yang mengekspresi ACE2 seperti paru-paru, saluran cerna dan jantung. Gejala pada fase ini umumnya ringan. Serangan kedua terjadi empat hingga tujuh hari setelah timbul gejala awal. Pada saat ini pasien masih demam dan mulai sesak, lesi di paru memburuk, limfosit menurun.

\section{Kuliah Kerja Nyata}

Kuliah Kerja Praktek (KKN) merupakan sarana bagi mahasiswa untuk mengaplikasikan teori-teori teori ke dalam bentuk pengabdian kepada masyarakat secara spesifik. KKN juga merupakan salah satu bentuk pengalaman khusus meliputi pendidikan, penelitian dan pengabdian masyarakat (Fandatiar et al., 2015). Diharapkan dengan adanya KKN ini mahasiswa dapat merealisasikan mata pelajaran keilmuan yang masih pada tataran teori. Selain penelitian berkelanjutan, juga berupa pengabdian dan pendampingan langsung kepada masyarakat. Sebagai upaya mengembangkan ilmu yang diperoleh sebelumnya. Selain itu, KKN juga 
memiliki skill yang dalam mengatasi dan memecahkan masalah yang terjadi di masyarakat sebagai media pembelajaran. Menjalin hubungan yang tidak terpisahkan dalam masyarakat, inilah tujuan utama yang akan kita hadapi di masa depan.

\section{METODOLOGI}

Program KKN dilaksanakan oleh mahasiswa Universitas Sebelas Maret. Lokasi pelaksanaannya adalah Dusun Selourik, Girimulyo, Ngargoyoso, Karanganyar Provinsi Jawa Tengah. Dalam proses mendapatkan rumusan masalah, metode yang digunakan adalah dengan mengamati langsung kehidupan masyarakat pada saat pandemi. Setelah itu, mendefinisikan semua masalah yang muncul dan mencari solusinya bila diperlukan. Kemudian kami mencoba untuk mengidealkan solusi-solusi yang kami kumpulkan agar program-program yang dihasilkan dan dilaksanakan kedepannya dapat memberikan dampak yang signifikan bagi masyarakat Desa Girimulyo.

Kegiatan KKN ini dilakukan menggunakan metode kualitatif, yakni dengan melakukan wawancara kepada narasumber yang kompeten. Selanjutnya dilakukan kegiatan observasi dan dilanjutkan dengan studi kepustakaan oleh penulis. Setelah data terkumpul dilakukan analisis data untuk dapat mengetahui peranan kegiatan $\mathrm{KKN}$ yang dapat dilaksanakan sesuai dengan program kerja yang sudah disusun sehingga kegiatan pengabdian yang dilakukan mellaui kegiatan KKN dapat dipublikasikan dalam bentuk artikel.

Tabel 1. Kegiatan KKN

\begin{tabular}{clrlrl}
\hline No. & \multicolumn{2}{c}{ Kegiatan } & & Sasaran Kegiatan & Keterangan \\
\hline 1. & Memberikan edukasi & umum & Masyarakat dusun & Grup Whatsapp \\
& kepada $\quad$ Masyarakat & Selourik & Selourik, Desa & \\
RW $\quad 09$ & mengenai & Perilaku & Girimulyo & \\
& Hidup Bersih dan Sehat (PHBS) & & \\
& secara online & & & \\
\hline 2. & Pengadaan fasilitas pendukung & Masyarakat Dusun & Dusun Sleourik \\
\hline
\end{tabular}




\begin{tabular}{|c|c|c|c|}
\hline & $\begin{array}{l}\text { untuk Masyarakat Dusun } \\
\text { Selourik RW } 09\end{array}$ & $\begin{array}{l}\text { Selourik Desa } \\
\text { Girimulyo }\end{array}$ & \\
\hline 3. & $\begin{array}{l}\text { Memberikan edukasi umum } \\
\text { kepada Masyarakat Selourik } \\
\text { RW } 09 \text { mengenai Perilaku } \\
\text { Hidup Bersih dan Sehat (PHBS) } \\
\text { secara offline }\end{array}$ & $\begin{array}{l}\text { Warga Dusun } \\
\text { Selourik, } \\
\text { Girimulyo }\end{array}$ & Dusun Sleourik \\
\hline 4. & $\begin{array}{ll}\text { Pendataan } & \text { masyarakat } \\
\text { terdampak covid-19 di Desa } \\
\text { Girimulyo }\end{array}$ & $\begin{array}{l}\text { Mahasiswa KKN } \\
\text { dan SATGAS } \\
\text { COVID-19 }\end{array}$ & $\begin{array}{l}\text { Kelurahan } \\
\text { Girimulyo }\end{array}$ \\
\hline 5. & $\begin{array}{l}\text { Bimbingan Belajar Anak Anak } \\
\text { Sekolah Dasar }\end{array}$ & $\begin{array}{l}\text { Anak }- \text { Anak } \\
\text { Sekolah Dasae }\end{array}$ & Rumah Mahasiswa \\
\hline 6. & $\begin{array}{lr}\text { Membantu } & \text { Pendistribusian } \\
\text { Bantuan } & \text { Sembako kepada } \\
\text { warga yang terdampak Pandemi }\end{array}$ & $\begin{array}{l}\text { Masyarakat } \\
\text { Terdampak } \\
\text { Pandemi COVID- } \\
19\end{array}$ & Desa Girimulyo \\
\hline 7. & Pembuatan sirup jahe & $\begin{array}{l}\text { Masyarakat Desa } \\
\text { Gitimulyo. }\end{array}$ & Rumah Mahasiswa \\
\hline
\end{tabular}

Penelitian yang dilakukan oleh Denny (2020) pada masa pandemi dapat mewujudkan karakter masyarakat yang sadar akan kebersihan di lingkungannya. Kegiatan yang dilakukan mampu memberikan edukasi akan pentingnya menjaga kebersihan untuk memutus rantai penyebaran covid-19. Kegiatan KKN yang dilaksanakan pada masa pandemi dapat membuat anak-anak memahami akan kesadaran mencuci tangan sebelum makan (Firdausi et al., 2020). Adanya kegiatan KKN saat pandemi memiliki kebermanfaatan untuk menjalankan Tri Dharma Perguruan Tinggi sebagai wujud pengabdian kepada masyarakat dalam mengimplementasikan ilmu yang diperoleh ketika di bangku perkuliahan. 


\section{HASIL DAN PEMBAHASAN}

Program KKN masa pandemi dilakukan dengan menerapkan protokol kesehatan yang ketat sesuai dengan himbauan pemerintah seperti phisical distancing dan Work From Home.

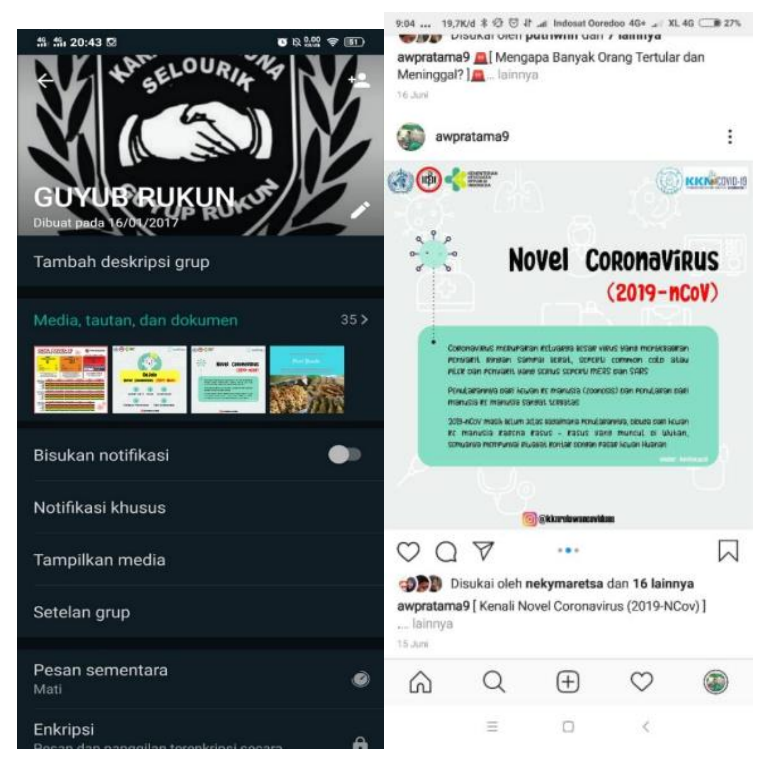

Gambar 1. Memberikan Edukasi Kepada Masyarakat mengenai PHBS (Sumber: Dokumen Pribadi)

Kegiatan pertama yang dilakukan selama KKN berlangsung yakni memberikan edukasi umum kepada masyarakat Selourik RW 09 mengenai Perilaku Hidup Bersih dan Sehat (PHBS) secara online. Program tersebut bertujuan untuk memberikan informasi kepada masyarakat tentang pentingnya praktik hidup bersih dan sehat (PHBS) mengenai pencegahan dan penularan Covid-19. Memberikan informasi melalui distribusi melalui media sosial seperti Instagram (IG) dan Whatsapp (WA). Media sosial whatsapp memegang peranan penting dalam pekerjaan edukasi ini karena WA menyediakan grup diskusi bagi penggunanya untuk memudahkan dalam menginformasikan kepada masyarakat. 

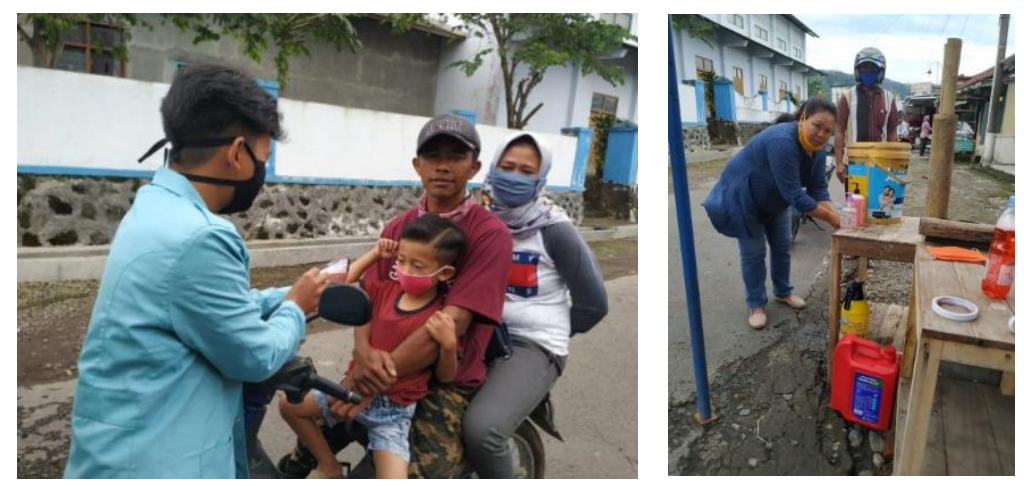

Gambar 2. Pembagian Ember Cuci Tangan dan Masker

(Sumber: Dokumen Pribadi)

Program kedua yang dilaksanakan adalah pengadaan fasilitas pendukung untuk Masyarakat Dusun Selourik RW 09. Program kerja yang dilaksanakan adalah mendistribusikan masker non medis kepada masyarakat sekitar. Mengingat virus corona mudah tertular melalui saluran pernafasan, pemberian hadiah ini diharapkan dapat meningkatkan kesadaran masyarakat akan pentingnya penggunaan masker di masa lalu. Kemudian, rencana tersebut juga menyediakan tempat bagi masyarakat untuk mencuci tangan dan desinfektan.

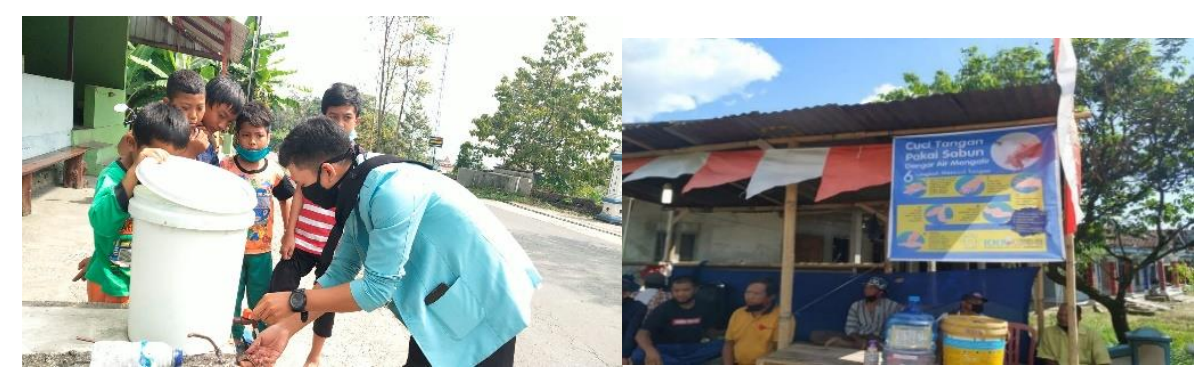

Gambar 3. Edukasi Mengenai PHBS

(Sumber: Dokumen Pribadi)

Program ketiga yang dilaksanakan adalah 3 memberikan edukasi umum kepada Masyarakat Selourik RW 09 mengenai Perilaku Hidup Bersih dan Sehat (PHBS) secara offline. Kegiatan yang dilakukan antara lain mengadakan soisalisasi COVID-19 dan cara cuci tangan yang benar. Mencuci tangan dapat membunuh virus dan bakteri di tangan. Disarankan untuk mencuci tangan dibanding menggunakan hand sanitizer (HS). Mencuci tangan lebih efektif membunuh virus dan bakteri, karena seluruh area tangan bisa dijangkau dengan air ledeng, dan sabun yang tepat dengan bahan aktif bisa membunuh bakteri. 
Disarankan menggunakan hand sanitizer saat bepergian karena tidak selalu bisa menerima air.

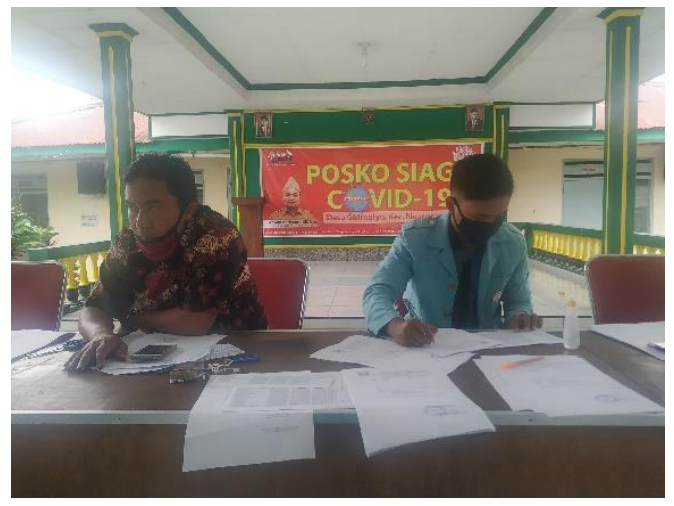

Gambar 4. Pendataan Masyarakat Terdampak Covid-19

(Sumber: Dokumen Pribadi)

Program keempat yang dilaksanakan adalah pendataan masyarakat terdampak Covid-19 di Desa Girimulyo. Kegiatan yang dilakukan berupa pengamanan posko Covid-19 bersama personel lain yang bertugas. Jika ada pendatang yaitu warga Katangan namun bebas melakukan perjalanan dari luar Kabupaten Kalangayan maka diwajibkan memberikan data diri dan membawa surat kesehatan yang diperoleh dari abses utama jalan Ngargoyoso. Selain itu, saya punya tugas lain untuk membuat daftar warga negara yang berhak mendapat subsidi dalam bentuk bantuan keuangan pemerintah. Populasi sasaran adalah mereka yang tidak terlalu kaya dan terkena dampak Covid secara finansial, seperti mereka yang telah dipecat atau berbisnis, namun terpaksa tutup karena peraturan pemerintah. Program ini saya jalankan bekerjasama dengan kelurahan setempat agar bisa berkoordinasi langsung dengan kelurahan.

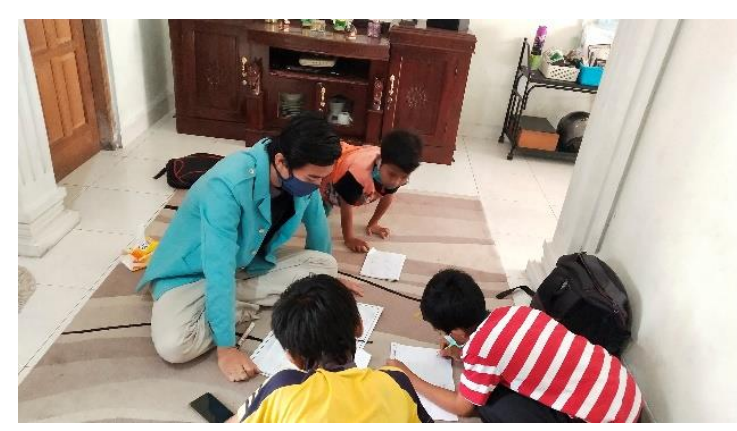

Gambar 5. Bimbingan Belajar

(Sumber: Dokumen Pribadi) 
Program kelima yang dilaksanakan adalah 5. Bimbingan Belajar. Saya dan juga mahasiswa KKN UNS lainnya bekerjasama untuk menjalankan program tersebut. Program yang kami jalankan menyediakan bimbingan belajar gratis bagi anak-anak warga sekitar agar tidak tertinggal di kelas. Layanan pendidikan diberikan karena banyak siswa SD yang berlibur dan tidak belajar pada saat pandemi karena tidak memiliki fasilitas penunjang. Banyak orang tua tidak memahami sistem pendidikan online, yang membuat pembelajaran terorganisir dan tidak mencapai hasil terbaik. Oleh karena itu, layanan pendidikan ini memang dapat membantu anak-anak dalam menguasai materi ajar. Berdasarkan pekerjaan yang telah dilakukan, anak-anak sangat tertarik untuk mengikuti panduan ini.

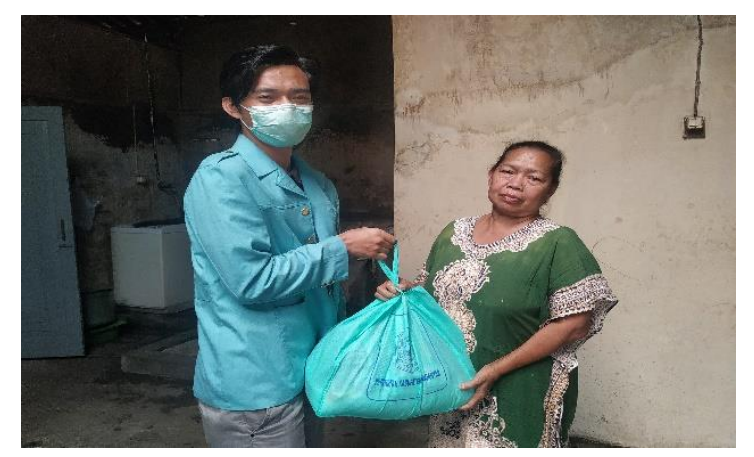

Gambar 6. Distribusi Sembako

(Sumber: Dokumen Pribadi)

Program keenam yang dilaksanakan adalah Membantu Pendistribusian Bantuan Sembako kepada warga yang terdampak Pandemi. Program ini merupakan program sederhana namun cukup membantu dalam mengupayakan kecukupan kebutuhan sehari-hari masyarakat setempat. Program ini dilaksanakan oleh pihak keluarahan bekerjasama dengan BABINKAMTIBMAS untuk membantu masyarakat yang terdampak pandemi COVID-19. 


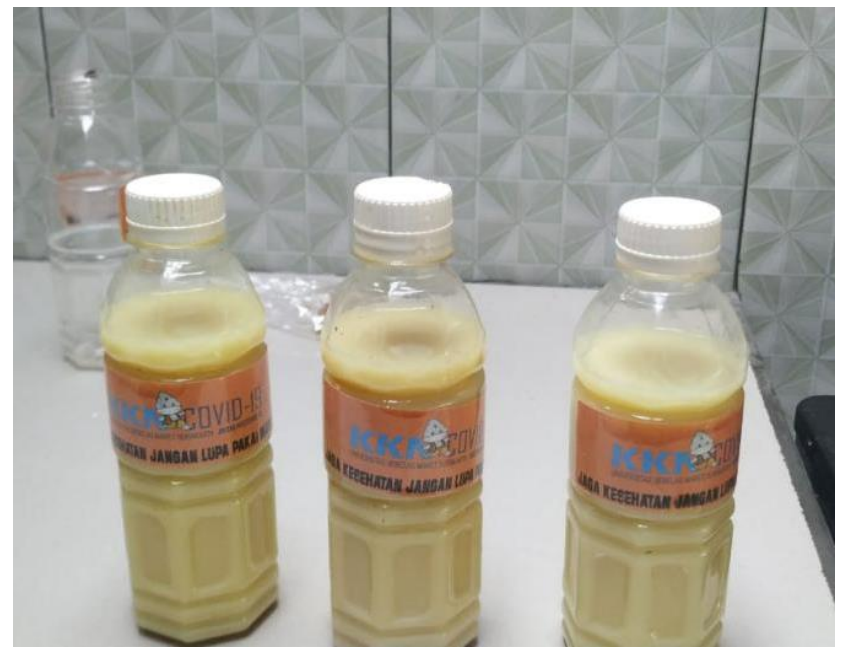

Gambar 7. Pembuatan Sirup Jahe

(Sumber: Dokumen Pribadi)

Program ketujuk yang dilaksanakan adalah Pembuatan sirup jahe. Jahe dipercaya memiliki sifat antibakteri dan antioksidan yang tinggi, sehingga dapat membantu meningkatkan daya tahan tubuh. Makan jahe di masyarakat sangat sederhana, yaitu dibakar, dihaluskan dan diseduh dengan air panas yang tidak begitu praktis dan ribet. Oleh karena itu diperlukan produk yang praktis dan mudah dikonsumsi yaitu sirup jahe. Kegiatan ini mengajak masyarakat untuk memproduksi sirup jahe agar lebih praktis bila ingin mengkonsumsinya. Tanpa mengurangi nilai gizi sirup jahe yang diproduksi secara massal, jahe juga membawa peluang bisnis yang luas karena popularitas dan popularitasnya.

\section{KESIMPULAN}

Berdasarkan kegiatan KKN yang dilakukan di Desa Selourik, Ngargoyoso, Kabupaten Karanganyar disimpulkan bahwa masyarakat ikut berpartisipasi dalam pelaksanaan KKN. Kegiatan sosialisasi mengenai bahaya Covid-19 berlangsung lancar dan banyak warga yang antusias degan adanya sosialisasi tersebut. Kegiatan belajar mengajar dapat mengubah pola pikir anak-anak akan kesadaran menjaga kebersihan dan kesehatan guna memutus rantai penyebaran Covid-19. Terlebih dengan adanya sosialisasi pembuatan sirup dari jahe akan menambah pengetahuan masyarakat untuk memanfaatkan hasil kebun yang bermanfaat 
menambah daya tahan tubuh sehingga dapat mengurangi resiko terpapar Covid19.

\section{ACKNOWLEDGEMENT}

Penulis mengucapkan terimakasih kepada Allah SWT atas nikmat dan karuniaNya ang melimpah. Penulis juga mengucapkan terima kasih kepada UNS Surakarta dan LPPPM UNS selaku penyelenggara Kuliah Kerja Nyata di tahun 2020. Terakhir penulis mengucapka terima kasih kepada Bapak Valiant Lukad Perdana Sutrisno, M.Pd selaku Dosen Pembimbing lapangan KKN serta masyarakat yan terlibat.

\section{DAFTAR PUSTAKA}

Al Hakim, R. R. (2020). Pencegahan Penularan Covid-19 Berbasis Aplikasi Android Sebagai Implementasi Kegiatan KKN Tematik Covid-19 di Sokanegara Purwokerto Banyumas. Community Engagement and Emergence Journal (CEEJ), 2(1), 7-13. https://doi.org/10.37385/ceej.v2i1.125

Denny, I. M., Putra, C., Regina, M., Tri, A., Yuhari, W., Studi, P., Seni, F., Seni, I., \& Denpasar, I. (2020). Edukasi Covid-19 Melalui Program KKN ISI Denpasar Untuk Mewujudkan Karakter Anak Yang Sadar Kebersihan Di Desa Carangsari. 8(2), 78-83.

Fandatiar, G., Supriyono, S., \& Nugraha, F. (2015). Rancang Bangun Sistem Informasi Kuliah Kerja Nyata (Kkn) Pada Universitas Muria Kudus. Simetris : Jurnal Teknik Mesin, Elektro Dan Ilmu Komputer, 6(1), 129. https://doi.org/10.24176/simet.v6i1.247

Firdausi, U., Candra, L. F. K., \& Ferri Karma, C. P. (2020). Pengabdian Masyarakat Dan Anak - Anak Melalui Kkn-T Mengenai Edukasi Pencegahan Covid-19 Di Desa Dukuh Cikupa. ABDIPRAJA (Jurnal Pengabdian Kepada Masyarakat), 1(1), 14. https://doi.org/10.31002/abdipraja.v1i1.3207

Gorbalenya, A. E., Baker, S. C., Baric, R. S., de Groot, R. J., Drosten, C., Gulyaeva, A. A., Haagmans, B. L., Lauber, C., Leontovich, A. M., Neuman, B. W., Penzar, D., Perlman, S., Poon, L. L. M., Samborskiy, D. V., Sidorov, 
I. A., Sola, I., \& Ziebuhr, J. (2020). The species Severe acute respiratory syndrome-related coronavirus: classifying 2019-nCoV and naming it SARSCoV-2. Nature Microbiology, 5(4), 536-544. https://doi.org/10.1038/s41564020-0695-z

Rangki, L., Alifariki, L. O., \& Dalla, F. (2020). Upaya pencegahan dan penanggulangan transmisi covid 19 melalui program KKN Tematik Mahasiswa Universitas Halu Oleo. Journal of Community Engagement in Health, 3(2), 266-274. http://jceh.org/

Siahaan, M. (2020). Dampak Pandemi Covid-19 Terhadap Dunia Pendidikan. Jurnal Kajian Ilmiah, 1(1), 73-80. https://doi.org/10.31599/jki.v1i1.265

Susilo, A., Rumende, C. M., Pitoyo, C. W., Santoso, W. D., Yulianti, M., Herikurniawan, H., Sinto, R., Singh, G., Nainggolan, L., Nelwan, E. J., Chen, L. K., Widhani, A., Wijaya, E., Wicaksana, B., Maksum, M., Annisa, F., Jasirwan, C. O. M., \& Yunihastuti, E. (2020). Coronavirus Disease 2019: Tinjauan Literatur Terkini. Jurnal Penyakit Dalam Indonesia, 7(1), 45. https://doi.org/10.7454/jpdi.v7i1.415

Syah, R. H. (2020). Dampak Covid-19 pada Pendidikan di Indonesia: Sekolah, Keterampilan, dan Proses Pembelajaran. SALAM: Jurnal Sosial Dan Budaya Syar-I, 7(5). https://doi.org/10.15408/sjsbs.v7i5.15314

Zhang, T., Wu, Q., \& Zhang, Z. (2020). Probable Pangolin Origin of SARS-CoV2 Associated with the COVID-19 Outbreak. Current Biology, 30(7), 13461351.e2. https://doi.org/10.1016/j.cub.2020.03.022 